\title{
PENGARUH KEDISIPLINAN DAN KEPUASAN KERJA TERHADAP KINERJA KARYAWAN PT. TRIKOMSEL OKE TBK MEDAN
}

\author{
Hendra Nazmi \\ Universitas Prima Indonesia \\ hendranazmi@unprimdn.ac.id
}

\begin{abstract}
The object of the study is PT. Trikomsel Oke Tbk Medan, because there was a decrease in employee performance at the company. Decline in employee performance occurs due to discipline in terms of accuracy is still less than optimal and lack of attention from the company that resulted in the presence of a sense of dissatisfaction. PT. Trikomsel Oke Tbk Medan is a company engaged in the distributor of mobile phones. This research uses quantitative approach, the type of research is descriptive quantitative and the nature of this research is descriptive explanatory. Data were collected by questionnaires, interviews, and documentation studies. The method of analysis used is multiple linear regression, coefficient of determination simultaneous and partial test. The population of this research is all employees who work in PT, Trikomsel Oke Tbk Medan which amounted to 107 people. The sampling technique used a saturated sample where

107 employees from PT. Trikomsel Oke Tbk Medan and 30 people from the branch office is OkeShop as a test of validity and reliability test. The results of this study indicate that the discipline and job satisfaction simultaneously and partially have a positive and significant effect on employee performance with the value of determination coefficient of 0.475 indicating that the discipline and job satisfaction affect employee performance with the percentage level $47.5 \%$ while the remaining $52.5 \%$ Is another factor that is not researched. The conclusion of this research is discipline and job satisfaction have influence both simultant and partially to employees performance at PT. Trikomsel Oke Tbk Medan.
\end{abstract}

Keywords: Discipline, Job Satisfaction, Employee Performance.

ABSTRAK : Peneliti mengambil objek pada PT. Trikomsel Oke Tbk Medan, alasan pemilihan objek disebabkan karena terdapatnya penurunan kinerja karyawan pada perusahaan. Penurunan kinerja karyawan terjadi dikarenakan kedisiplinan dalam hal ketepatan waktu masih kurang optimal disebabkan karyawan masih sering datang terlambat serta kurangnya perhatian dari perusahaan yang mengakibatkan terdapatnya rasa ketidak puasaan bagi karyawan. Metode penelitian yang digunakan oleh peneliti adalah pendekatan kuantitatif, jenis penelitian adalah deskriptif kuantitatif dan sifat penelitian deskriptif explanatory. Metode pengumpulan data dilakukan dengan kuesioner, wawancara, dan studi dokumentasi. Metode analisis yang digunakan adalah regresi linier berganda, koefisien determinasi pengujian secara simultan dan parsial. Populasi penelitian ini adalah seluruh karyawan yang bekerja di PT, Trikomsel Oke Tbk Medan yang berjumlah 107 orang. Teknik pengambilan sampel menggunakan sampel jenuh dimana 107 orang karyawan dari PT. Trikomsel Oke Tbk Medan dan 30 orang dari kantor cabang yaitu OkeShop sebagai uji validitas dan uji reliabilitas. Hasil hipotesis menunjukkan bahwa kedisiplinan dan kepuasan kerja secara simultan maupun parsial berpengaruh positif dan signifikan terhadap kinerja, dimana koefisien determinasinya sebesar 47,5\%. Kesimpulan dari penelitian ini adalah kedisiplinan dan kepuasan kerja berpengaruh baik secara simultan maupun secara parsial terhadap kinerja karyawan pada PT. Trikomsel Oke Tbk Medan.

Kata Kunci : Kedisiplinan, Kepuasan Kerja dan Kinerja Karyawan. 


\section{Pendahuluan}

Perusahaan selalu menginginkan kemajuan dalam usaha yang dijalaninya. Kemajuan dalam usaha tidak terlepas dari laba yang besar karena dengan laba yang besar keberlangsungan hidup perusahaan dapat terjamin. Kemajuan dalam perusahaan ditentukan dari sumber daya manusia yang bekerja di perusahaan tersebut.

Sumber daya yang baik dapat dilihat dari kinerja karyawannya. Kinerja merupakan hasil yang dicapai oleh seseorang sesuai dengan tugas, wewenang dan tanggung jawabnya dalam upaya untuk mencapai tujuan perusahaan. Untuk mencapai kinerja yang tinggi, perusahaan harus memperhatikan disiplin kerja karyawan dan kepuasan kerja karyawan.

Kedisiplinan merupakan suatu tingkah laku dan perbuatan yang sesuai dengan peraturan baik tertulis maupun tidak tertulis, kedisiplinan dapat ditegakkan maka tujuan perusahaan dapat dicapai secara efektif dan efisien. Disamping itu, untuk tetap mempertahankan karyawan yang memiliki kinerja tinggi, perusahaan harus memperhatikan tuntutan karyawan agar kepuasan karyawan terpenuhi sehingga kinerja karyawan dapat tetap stabil.

Berdasarkan uraian diatas, maka penulis merasa tertarik untuk meneliti dan membahas lebih lanjut permasalahannya dengan judul : "Pengaruh Kedisiplinan Dan Kepuasan Kerja Terhadap Kinerja Karyawan PT. Trikomsel Oke Tbk Medan”.

\section{Landasan Teori}

\subsection{Kedisiplinan}

Menurut Hasibuan (2009:193) Kedisiplinan adalah fungsi operatif keenam dari Manajemen Sumber Daya Manusia. Kedisiplinan merupakan fungsi operatif MSDM yang terpenting karena semakin baik disiplin karyawan, semakin tinggi prestasi kerja yang dapat dicapainya. Tanpa disiplin karyawan yang baik, sulit bagi organisasi perusahaan mencapai hasil yang optimal.

Menurut Singodimedjo dalam Sutrisno (2009:86) disiplin adalah sikap kesediaan dan kerelaan seseorang untuk mematuhi dan menaati norma-norma peraturan yang berlaku disekitarnya.

Menurut Davis dalam Sinambela (2016:334) disiplin penerapan pengelolaan untuk memperteguh dan melaksanakan pedomanpedoman organisasi.
Menurut Singodimejo dalam Sutrisno (2009:89) ada berbagai faktor-faktor kedisiplinan sebagai berikut:

a. Besar kecilnya pemberian kompensasi

Besar kecilnya kompensasi dapat mempengaruhi tegaknya disiplin. Para karyawan akan mematuhi segala peraturan yang berlaku, bila ia merasa mendapat jaminan balas jasa yang setimpal dengan jerih payahnya yang telah dikontribusikan bagi perusahaan.

b. Ada tidaknya keteladanan pimpinan dalam perusahaan

Keteladanan pimpinan sangat penting sekali, karena dalam lingkungan perusahaan, semua karyawan akan selalu memperhatikan bagaimana pimpinan dapat menegakkan disiplin dirinya dan bagaimana ia dapat mengendalikan dirinya dari ucapan, perbuatan, dan sikap yang dapat merugikan aturan disiplin yang sudah ditetapkan.

c. Ada tidaknya aturan pasti yang dapat dijadikan pegangan

Pembinaan disiplin tidak akan dapat terlaksana dalam perusahaan, bila tidak ada aturan tertulis yang pasti untuk dapat dijadikan pegangan bersama. Disiplin tidak mungkin ditegakkan bila peraturan yang dibuat hanya berdasarkan instruksi lisan yang dapat berubah-ubah sesuai dengan kondisi dan situasi.

d. Keberanian pimpinan dalam mengambil tindakan

Bila ada seseorang karyawan yang melanggar disiplin, maka perlu ada keberanian pimpinan untuk mengambil tindakan yang sesuai dengan tingkat pelanggaran yang dibuatnya. Dengan adanya tindakan terhadap pelanggar disiplin, sesuai dengan sanksi yang ada.

e. Ada tidaknya pengawasan pimpinan

Dalam setiap kegiatan yang dilakukan oleh perusahaan perlu ada pengawasan, yang akan mengarahkan para karyawan agar dapat melaksanakan pekerjaan dengan tepat dan sesuai dengan yang telah ditetapkan.

f. Ada tidaknya perhatian kepada para karyawan Karyawan adalah manusia yang mempunyai perbedaan karakter antara yang satu dengan yang lain. Seorang karyawan tidak hanya puas dengan penerimaan kompensasi yang tinggi, pekerjaan yang menantang, tetapi juga mereka masih membutuhkan perhatian yang besar dari pimpinannya sendiri.

g. Diciptakan kebiasaan-kebiasaan yang mendukung tegaknya disiplin 
Kebiasaan-kebiasaan positif itu antara lain;

a. Saling menghormati, bila ketemu dilingkungan pekerjaan.

b. Memberikan pujian sesuai dengan tempat dan waktunya, sehingga para karyawan akan turut merasa bangga dengan pujian tersebut.

c. Sering mengikut sertakan karyawan dalam pertemuan-pertemuan, apalagi pertemuan yang berkaitan dengan nasib dan pekerjaan mereka.

d. Memberi tahu bila ingin meninggalkan tempat kepada rekan sekerja, dengan menginformasikan, kemana dan untuk urusan apa, walaupun kepada bawahan sekalipun.

Menurut Hasibuan (2009:194) pada dasarnya banyak indikator yang mempengaruhi tingkat kedisiplinan karyawan suatu organisasi, di antaranya :

a. Tujuan dan Kemampuan

Tujuan dan kemampuan ikut mempengaruhi tingkat kedisiplinan karyawan. Tujuan yang akan dicapai harus jelas dan ditetapkan secara ideal serta cukup menantang bagi kemampuan karyawan.

b. Teladan Pimpinan

Teladan pimpinan sangat berperan dalam menentukan kedisiplinan karyawan karena pimpinan dijadikan teladan dan panutan oleh para bawahannya. Pimpinan harus memberi contoh yang baik, berdisiplin baik, jujur, adil, serta sesuai kata dengan perbuatan. Dengan teladan pimpinan yang baik, kedisiplinan bawahan pun akan ikut baik

c. Balas Jasa

Balas jasa (gaji atau kesejahteraan) ikut mempengaruhi kedisiplinan karyawan karena balas jasa akan memberikan kepuasan dan kecintaan karyawan terhadap perusahaan/pekerjaannya. Jika kecintaan karyawan semakin baik terhadap pekerjaan, kedisiplinan mereka akan semakin baik pula.

d. Keadilan

Keadilan yang dijadikan dasar kebijaksanaan dalam pemberian balas jasa (pengakuan) atau hukuman akan merangsang terciptanya kedisiplinan karyawan yang baik. Manajer yang cakap dalam memimpin selalu berusaha bersikap adil terhadap semua bawahannya.

e. Waskat

Waskat (pengawasan ketat) adalah tindakan nyata yang paling efektif dalam mewujudkan kedisiplinan karyawan perusahaan. Dengan waskat berarti atasan harus aktif dan langsung mengawasi perilaku, moral, sikap, gairah kerja, dan prestasi kerja bawahannya.

f. Sanksi Hukuman

Sanksi hukuman berperan penting dalam memelihara kedisiplinan karyawan. Dengan sanksi hukuman yang semakin berat, karyawan akan semakin takut melanggar peraturan-peraturan perusahaan, sikap, dan perilaku indisipliner karyawan akan berkurang.

g. Ketegasan

Ketegasan pimpinan dalam melakukan tindakan akan mempengaruhi kedisiplinan karyawan perusahaan. Pimpinan harus berani dan tegas, bertindak untuk menghukum setiap karyawan yang indisipliner sesuai dengan sanksi hukuman yang telah ditetapkan. Pimpinan yang berani bertindak tegas menerapkan hukuman bagi karyawan yang indisipliner akan disegani dan diakui kepemimpinannya oleh bawahan.

h. Hubungan Kemanusiaan

Manajer harus berusaha menciptakan suasana hubungan kemanusiaan yang serasi serta mengikat, vertikal maupun horizontal di antara semua karyawannya. Terciptanya human relationship yang serasi akan mewujudkan lingkungan dan suasana kerja yang nyaman.

\subsection{Kepuasan Kerja}

Menurut Badriyah (2015:229) Kepuasan kerja adalah sikap atau perasaan karyawan terhadap aspek-aspek yang menyenangkan atau tidak menyenangkan mengenai pekerjaan yang sesuai dengan penilaian masing-masing pekerja.

Menurut Handoko (2014:193) kepusan kerja (job satisfaction) adalah keadaan emosional yang menyenangkan atau tidak menyenangkan dengan mana para karyawan memandang pekerjaan mereka.

Menurut Robbins dalam Wibowo (2014:413) kepuasan kerja adalah sikap umum terhadap pekerjaan sesorang yang menunjukkan perbedaan antara jumlah penghargaan yang diterima pekerja dan jumlah yang mereka yakini seharusnya mereka terima.

Menurut Hasibuan (2009:203) faktor-faktor yang mempengaruhi kepuasan kerja adalah :

a. Balas jasa yang adil dan layak.

b. Penempatan yang tepat sesuai dengan keahlian.

c. Berat ringannya pekerjaan.

d. Suasana dan lingkungan pekerjaan. 
e. Peralatan yang menunjang pelaksanaan pekerjaan.

f. Sikap pimpinan dalam kepemimpinannya.

g. Sifat pekerjaan monoton atau tidak.

Menurut Spector dalam Badriyah (2015:241) mendefinisikan kepuasan sebagai cluster perasaan evaliatif tentang pekerjaan. Ia mengidentifikasikan indikator kepuasan kerja dari Sembilan aspek, yaitu :

a. Upah, jumlah dan rasa keadilannya

b. Promosi, peluang dan rasa keadilan untuk mendapatkan promosi

c. Supervisi, keadilan dan kompetensi penugasan manajerial oleh penyelia

d. Benefit, asuransi, liburan, dan bentuk fasilitas yang lain

e. Contingent rewards, rasa hormat, diakui, dan diberikan apresiasi

f. Operating procedures, kebijakan, prosedur, dan aturan

g. Co-workers, rekan kerja yang menyenangkan dan kompeten

h. Nature of work, tugas itu dapat dinikmati atau tidak

i. Communication, berbagai informasi di dalam organisasi, baik verbal maupun nonverbal

\subsection{Kinerja}

Menurut Mangkunegara (2013:67) kinerja adalah hasil kerja secara kualitas dan kuantitas yang dicapai oleh seorang pegawai dalam melaksanakan tugasnya sesuai dengan tanggung jawab yang diberikan kepadanya.

Menurut Hasibuan dalam Yani (2012:117) kinerja adalah suatu hasil kerja yang dicapai seseorang dalam melaksanakan tugas-tugas yang dibebankan kepadanya yang didasarkan atas kecakapan, pengalaman, dan kesungguhan serta waktu.
Menurut Darmawan (2013:177) kinerja sebagai hasil kerja yang dicapai seseorang secara kualitas dan kuantitas harus dipantau secara terus menerus perkembangannya.

Menurut Timple dalam Darmawan 2013:192) Faktor-faktor kinerja terdiri dari:

a. Faktor Internal, yaitu faktor yang dihubungkan dengan sifat-sifat seseorang

b. Faktor Eksternal, yaitu faktor-faktor yang mempengaruhi kinerja seseorang yang berasal dari lingkungan.

Menurut Sutrisno (2011:179-180) indikator kinerja adalah :

a. Quality, merupakan tingkat sejauh mana proses atau hasil pelaksanaan kegiatan mendekati kesempurnaan atau mendekati tujuan yang diharapkan.

b. Quantity, merupakan jumlah yang dihasilkan. Misalnya jumlah rupiah, unit dan siklus kegiatan yang dikerjakan.

c. Timeliness, merupakan sejauh mana suatu kegiatan diselesaikan pada waktu yang telah dikehendaki, dengan memperhatikan koordinasi output lain serta waktu yang tersedia untuk kegiatan orang lain.

d. Cost effectiveness, merupakan tingkat sejauh mana penggunaan sumber daya organisasi dimaksimalkan untuk penggunaan sumber daya.

e. Need for supervision, merupakan tingkat sejauh mana seorang pekerja dapat melaksanakan suatu fungsi pekerjaan tanpa memerlukan pengawasan seorang supervisor untuk mencegah tindakan yang kurang diinginkan.

f. Interpersonal impact, merupakan tingkat sejauh mana pegawai memelihara harga diri, nama baik, dan kerja sama diantara rekan kerja dan bawahan.

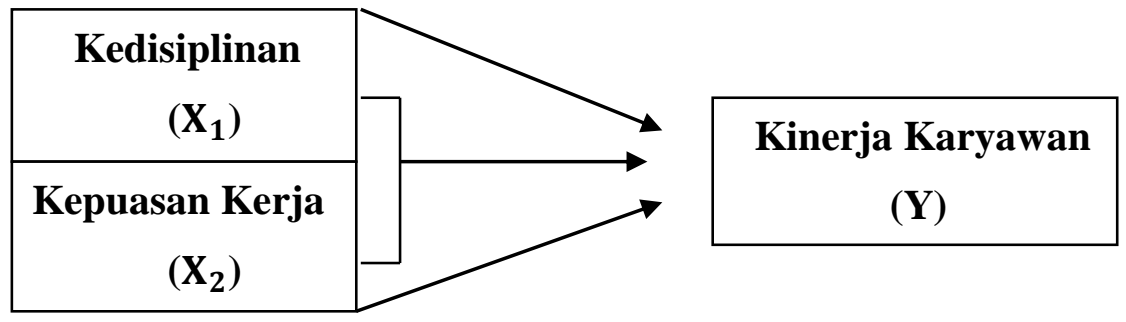

Gambar 1. Kerangka Konseptual

Adapun hipotesis yang dibuat oleh peneliti b. Kepuasan kerja berpengaruh terhadap Kinerja sebagai berikut :

a. Kedisiplinan berpengaruh terhadap Kinerja karyawan pada karyawan pada PT. Trikomsel Oke Tbk PT. Trikomsel Oke Tbk Medan.

Medan. 
c. Kedisiplinan dan Kepuasan kerja berpengaruh terhadap Kinerja karyawan PT. Trikomsel Oke Tbk Medan.

\section{Metode Penelitian}

Lokasi penelitian ini dilakukan di PT. Trikomsel Oke Tbk Medan di jalan Jend. Gatot Subroto No.166 Medan. Waktu penyusunan ini akan direncanakan selama 6 (enam) bulan mulai dari bulan Juli sampai dengan bulan Desember 2016.

Pendekatan penelitian yang digunakan adalah pendekatan kuantitatif. Jenis penelitian yang digunakan adalah deskriptif kuantitatif. Sifat penelitian yang digunakan adalah deskriptif explanatory. Penelitian bertujuan untuk menjelaskan bagaimana hubungan antara variabel dari suatu fenomena yang sedang diteliti.

Populasi yang diambil dalam penelitian ini adalah seluruh karyawan yang berjumlah 107 orang pada PT. Trikomsel Oke Tbk Medan. Penelitian ini menggunakan penarikan sampel secara jenuh. Sampling jenuh adalah teknik penentuan sampel bila semua anggota populasi digunakan sebagai sampel. Dalam penelitian ini sampel yang digunakan oleh peneliti adalah seluruh populasi yang berjumlah 107 orang karyawan PT. Trikomsel Oke Tbk Medan. Untuk uji validitas dan reliabilitas terdiri dari 30 orang karyawan yang diuji dikantor cabang yaitu OkeShop yang terletak di Plaza Millenium atau jalan Kapten Muslim.

Sebelum model regresi yang diperoleh digunakan untuk menguji hipotesis, terlebih dahulu model tersebut diuji asumsi klasik. Uji asumsi klasik yang dilakukan meliputi : uji normalitas, uji multikolinearitas, dan uji heteroskedastisitas. Model analisis data ini menggunakan analisis regresi berganda.

\section{Hasil Pembahasan}

Analisis regresi linier berganda digunakan untuk memprediksi perubahan variabel dependen yang dijelaskan/dihubungkan oleh dua atau lebih variabel independen sebagai faktor prediktor yang dimanipulasi dan untuk mengetahui ada tidaknya pengaruh antara variabel independen terhadap variabel dependen.

Tabel 1. Hasil Analisis Regresi Linier Berganda Coefficients $^{\mathrm{a}}$

\begin{tabular}{|c|c|c|c|c|c|}
\hline \multirow[b]{2}{*}{ Model } & \multicolumn{2}{|c|}{ Unstandardized Coefficients } & $\begin{array}{l}\text { Standardized } \\
\text { Coefficients }\end{array}$ & & \\
\hline & B & Std. Error & Beta & $\mathrm{t}$ & Sig. \\
\hline $1 \quad($ Constant $)$ & 3.183 & 3.784 & & .841 & .40 \\
\hline Kedisiplinan & .630 & .112 & .450 & 5.606 & .00 \\
\hline Kepuasan Kerja & .451 & .102 & .356 & 4.433 & .000 \\
\hline
\end{tabular}

a. Dependent Variable: kinerja

Sumber : Hasil Penelitian, 2017 (Data diolah)

\section{Kinerja $=$ 3,183 + 0,630 Kedisiplinan + 0,451 Kepuasan kerja}

Makna dari persamaan regresi linier berganda diatas adalah :

a. Konstanta sebesar 3,183 menyatakan bahwa jika kedisiplinan dan kepuasan kerja tidak ada atau konstan maka kinerja karyawannya sebesar 3,183 satuan.

b. Koefisien regresi kedisiplinan sebesar 0,630 dan bernilai positif, hal ini menyatakan bahwa setiap kenaikan kedisiplinan 1 satuan akan meningkatkan kinerja karyawan sebesar 0,630 satuan dengan anggapan variabel lainnya tetap.

c. Koefisien regresi kepuasan kerja sebesar 0,451 dan bernilai positif, hal ini menyatakan bahwa setiap kenaikan kepuasan kerja 1 satuan akan menyebabkan kenaikan kinerja karyawan sebesar 0,451 satuan dengan anggapan variabel lainnya tetap. 
Tabel 2. Hasil analisis koefisien determinasi

Uji Koefisien Determinasi

Model Summary ${ }^{\mathrm{b}}$

\begin{tabular}{|l|r|r|r|c|}
\hline Model & $\mathrm{R}$ & R Square & $\begin{array}{c}\text { Adjusted R } \\
\text { Square }\end{array}$ & $\begin{array}{c}\text { Std. Error of the } \\
\text { Estimate }\end{array}$ \\
\hline 1 & $.696^{\mathrm{a}}$ & .485 & .475 & 4.67843 \\
\hline
\end{tabular}

a. Predictors: (Constant), kedisiplinan, kepuasan kerja

b. Dependent Variable: Kinerja

Sumber : Hasil Penelitian, 2017 (Data diolah)

Hasil Uji Koefisien Determinasi diperoleh nilai $R$ square sebesar 0,485 hal ini berarti $47,5 \%$ dari variasi variabel dependen kinerja karyawan yang dapat dijelaskan oleh variasi variabel independen kedisiplinan dan kepuasan kerja sedangkan sisanya sebesar 52,5\% (100\% $47,5 \%)$ dijelaskan oleh variabel lain yang tidak diteliti pada penelitian ini seperti kepemimpinan, stress kerja dan lain-lain.

Tabel 3. Hasil Uji Statistik F (Simultan)

\section{Uji F}

ANOVA $^{b}$

\begin{tabular}{|c|c|c|c|c|c|c|}
\hline \multicolumn{2}{|c|}{ Model } & $\begin{array}{l}\text { Sum of } \\
\text { Squares }\end{array}$ & Df & Mean Square & $\mathrm{F}$ & Sig. \\
\hline 1 & Regression & 2140.107 & 2 & 1070.053 & 48.888 & $.000^{\mathrm{a}}$ \\
\hline & Residual & 2276.323 & 104 & 21.888 & & \\
\hline & Total & 4416.430 & 106 & & & \\
\hline
\end{tabular}

a. Predictors: (Constant), kedisiplinan, kepuasan kerja

b. Dependent Variable: kinerja

Sumber : Hasil Penelitian, 2017 (Data diolah)

Uji signifikan simultan atau bersama-sama (uji statistik F) menghasilkan nilai $\mathrm{F}$ hitung sebesar 48,888. Pada derajat bebas $1(\mathrm{df} 1)=\mathrm{k}-$ $1=3-1=2$, dan derajat bebas $2(\mathrm{df} 2)=\mathrm{n}-\mathrm{k}=$ 107-3 = 104, dimana $\mathrm{n}=$ jumlah sampel, $\mathrm{k}=$ jumlah variabel, maka nilai $\mathrm{F}$ tabel pada taraf kepercayaan signifikan 0,05 adalah 3,08 dengan demikian dari hasil perhitungan SPSS diperoleh nilai $\mathrm{F}$ hitung $=48,888>\mathrm{F}$ tabel $=3,08$ dengan tingkat signifikan 0,000 karena $\mathrm{F}$ hitung = 48,888 > $\mathrm{F}$ tabel $=3,08$ dan probabilitas signifikan $0,000<0,05$, Makan H1 diterima artinya kedisiplinan dan kepuasan kerja secara simultan berpengaruh positif dan signifikan terhadap kinerja karyawan PT. Trikomsel Oke Tbk Medan.

Tabel 4. Hasil Uji Statistik T (Parsial)

Coefficients $^{\mathrm{a}}$

\begin{tabular}{|ll|r|r|r|r|r|}
\hline \multirow{2}{*}{ Model } & \multicolumn{2}{|c|}{$\begin{array}{c}\text { Unstandardized } \\
\text { Coefficients }\end{array}$} & \multicolumn{2}{c|}{$\begin{array}{c}\text { Standardized } \\
\text { Coefficients }\end{array}$} & \multirow{2}{*}{} & \\
\cline { 2 - 4 } & \multicolumn{1}{|c|}{ B } & Std. Error & \multicolumn{1}{c|}{ Beta } & \multicolumn{1}{c|}{ T } & \multicolumn{1}{c|}{ Sig. } \\
\hline 1 & (Constant) & 3.183 & 3.784 & & .841 & .402 \\
& Kedisiplinan & .630 & .112 & .450 & 5.606 & .000 \\
& Kepuasan kerja & .451 & .102 & .356 & 4.433 & .000 \\
\hline
\end{tabular}

a. Dependent Variable: kinerja

Sumber : Hasil penelitian, 2017 (Data diolah)

Nilai t tabel untuk probabilitas 0,05 pada derajat bebas $(\mathrm{df})=104$ adalah 1,98304. Dengan demikian hasil dari Uji t dapat dijelaskan sebagai berikut : a. Hasil perhitungan uji $t$ secara parsial diperoleh nilai t hitung kedisiplinan sebesar 5,606 dengan nilai signifikan sebesar 0,000 . Nilai $\mathrm{t}$ hitung $>\mathrm{t}$ tabel atau 5,606 $>1,98304$ 
maka H1 diterima artinya kedisiplinan berpengaruh positif dan signifikan terhadap kinerja karyawan di PT. Trikomsel Oke Tbk Medan.

b. Hasil perhitungan uji $\mathrm{t}$ secara parsial diperoleh nilai t hitung kepuasan kerja sebesar 4,433 dengan nilai signifikan sebesar 0,000 . Nilai $\mathrm{t}$ hitung $>\mathrm{t}$ tabel atau 4,433>1,98304 maka H1 diterima artinya kepuasan kerja berpengaruh positif dan signifikan terhadap kinerja karyawan di PT. Trikomsel Oke Tbk Medan.

\subsection{Pengaruh Kedisiplinan Terhadap Kinerja Karyawan}

Hasil analisis menunjukkan bahwa hipotesis pertama yang menyatakan kedisiplinan berpengaruh positif dan signifikan terhadap kinerja karyawan PT. Trikomsel Oke Tbk Medan dapat diterima. Hal ini dibuktikan dengan nilai $t$ hitung sebesar 5,606 dengan nilai signifikan sebesar 0,000. Nilai t hitung > t tabel 5,606 > 1,98304 maka H1 diterima.

Hasil penelitian ini sejalan dengan hasil penelitian terdahulu yang dilakukan oleh Abd.Rasyid Syamsuri (2014) dalam penelitiannya berjudul Analisis Pengaruh Pendidikan, Pengawasan Kerja Dan Disiplin Terhadap Kinerja Pegawai Dinas Pendidikan Kabupaten Mandailing Natal yang menyatakan bahwa disiplin kerja berpengaruh secara positif dan signifikan terhadap kinerja.

Hasil penelitian ini juga didukung oleh teori yang dikemukakan dalam Dermawan (2013:41), pelaksanaan dan peningkatan disiplin menjadi bagian penting dalam manajemen sumber daya manusia sebagai salah satu faktor penting untuk meningkatkan produktivitas dan kinerja karyawan.

\subsection{Pengaruh Kepuasan Kerja Terhadap Kinerja Karyawan}

Hasil analisis menunjukkan bahwa hipotesis kedua yang menyatakan kepuasan kerja berpengaruh positif dan signifikan terhadap kinerja karyawan PT. Trikomsel Oke Tbk Medan dapat diterima. Hal ini dibuktikan dengan nilai $\mathrm{t}$ hitung kepuasan kerja sebesar 4,433 dengan nilai signifikan sebesar 0,000 . Nilai t hitung $>\mathrm{t}$ tabel atau 4,433 > 1,98304 maka $\mathrm{H} 1$ diterima.

Hasil penelitian ini sejalan dengan hasil penelitian terdahulu yang dilakukan oleh Diana Sulianti dan K. L. Tobing (2009) dalam penelitiannya yang berjudul Pengaruh Komitmen Organisasi dan Kepuasan Kerja Terhadap
Kinerja Karyawan PT. Perkebunan Nusantara III di Sumatera Utara yang menyatakan bahwa kepuasan kerja berpengaruh secara positif dan signifikan terhadap kinerja.

Hal ini sejalan dengan teori Sopiah (2008:171) Kepuasan kerja dirasakan karyawan setelah karyawan tersebut membandingkan antara apa yang dia harapkan akan dia peroleh dari hasil kerjanya dengan apa yang sebenarnya dia peroleh dari hasil kerjanya.

\section{KESIMPULAN}

Setelah melakukan analisa terhadap data-data yang diperoleh, peneliti menyimpulkan hasil penelitian ini sebagai berikut:

a. Kedisiplinan berpengaruh positif dan signifikan terhadap kinerja karyawan PT. Trikomsel Oke Tbk Medan.

b. Kepuasan Kerja berpengaruh positif dan signifikan terhadap kinerja karyawan PT. Trikomsel Oke Tbk Medan.

c. Kedisiplinan dan Kepuasan kerja berpengaruh positif dan signifikan terhadap kinerja karyawan PT. Trikomsel Oke Tbk Medan. Hasil uji koefisien determinasi menunjukkan $47,5 \%$ dari variasi variabel independen kedisiplinan dan kepuasan kerja sedangkan sisanya sebesar $52,5 \%$ dijelaskan oleh variabel lain yang tidak diteliti pada penelitian ini.

\section{DAFTAR PUSTAKA}

Badriyah, Mila. Manajemen Sumber Daya Manusia. Cetakan Kesatu, Bandung: Pustaka Setia, 2015.

Darmawan, Didit. Prinsip Prinsip Perilaku Organisasi. Cetakan Pertama, Surabaya: PT. JePe Press Media Utama, 2013.

Hasibuan, Malayu SP. Manajemen Sumber Daya Manusia. Ed. Revisi, Jakarta: PT. Bumi Aksara, 2009.

Handoko, Hani. Manajemen Personalia Dan Sumber Daya Manusia. Cetakan Keduapuluhsatu, Yogyakarta: BPFE, 2014.

Mangkunegara, Anwar Prabu. Manajemen umber Daya Manusia Perusahaan.

Cetakan Keduabelas, Bandung: PT. Remaja Rosdakarya, 2013.

Sinambela, Lijan Poltak. Manajemen Sumber Daya Manusia. Cetakan Pertama, Jakarta: Bumi Aksara, 2016.

Sopiah. Perilaku Organisasi. Ed. Pertama, Yogyakarta: Andi, 2008.

Sutrisno, Edy. Manajemen Sumber Daya Manusia. Cetakan Pertama, Jakarta: 
Kencana, 2009.

Syamsuri, Abd rasyid. Analisis Pengaruh Pendidikan, Pengawasan Kerja Dan Disiplin Terhadap Kinerja Pegawai Dinas Pendidikan Kabupaten Mandailing Natal. 2014.

Tobing, dan Diana Sulianti. Pengaruh Komitmen Organisasi Dan Kepuasan Kerja
Terhadap Kinerja Karyawan PT. Perkebunan Nusantara III di Sumatera Utara. 2009.

Wibowo. Manajemen Kinerja. Cetakan Keempat, Jakarta: Rajawali Pers, 2014. Yani. Manajemen Sumber Daya Manusia. Jakarta: Mitra Wacana Media, 2012. 